Article

\title{
How Can Technical Aspects Help Improving K-Ar Isotopic Data of Illite-Rich Clay Materials into Meaningful Ages? The Case of the Dominique Peter Uranium Deposit (Saskatchewan, Canada)
}

\author{
Norbert Clauer \\ Institut de Physique du Globe de Strasbourg, Université de Strasbourg-Centre National de la Recherche \\ Scientifique, 1 Rue Blessig, 67084 Strasbourg, France; nclauer@unistra.fr
}

Received: 11 June 2020; Accepted: 17 July 2020; Published: 27 July 2020

\begin{abstract}
Previously published K-Ar dating results of $<2 \mu \mathrm{m}$ illite separates from uranium-hosting and associated barren rocks from Dominique Peter district of the Carswell circular structure in the Athabasca Basin (Canada) were considered to trace four distinct tectonic-thermal events at $1447 \pm 45,1282 \pm 40$ and $1184 \pm 15$ (all errors at $\pm 2 \mathrm{Ma}$, with a younger, less constrained episode at $\sim 900 \mathrm{Ma}$. Recent analyses of K-Ar ages of additional $<0.2 \mu \mathrm{m}$ illite fractions from a few initial samples demonstrate that the intermediate ages at $\sim 1280$ and 1185 Ma result, in fact, from mixing of two generations of illite that precipitated at $\sim 1450$ and $\sim 900 \mathrm{Ma}$. They have, therefore, no stratigraphic value, while the two tectonic-thermal episodes at $1448 \pm 48$ and $937 \pm 39$ Ma appear to be historically sound. In fact, the analytical procedure of isotopic dating clay materials is of more importance than is often stated. For instance, a safe way to evaluate and constrain best numerical isotopic data of clay separates into ages is combining data of two size splits from several samples. If such age data, especially from size fractions of indurated host rocks, are scattered and point towards the higher data of the coarser fractions, they are potentially enriched in earlier crystallized K-rich components, and should consequently be discarded. The occurrence of detrital or early-crystallized components in clay-rich separates becomes a serious concern when comparing ages generated by various isotopic methods on mineral separates of various whole rocks. It is especially verified in very old, metal-rich deposits such as the uranium-rich deposits of the Saskatchewan Basin. These deposits and their host rocks were studied extensively by a large spectrum of isotopic methods on many types of rocks in a widely dispersed area, and for which the numerical statistics became, sometimes, more central in the interpretation than the specificity of the successive events in the host rocks.
\end{abstract}

Keywords: downsizing illite separates; K-Ar dating; uranium deposits; tectonic-thermal activity; Dominique Peter district; Carswell circular structure; Saskatchewan (Canada)

\section{Introduction}

Isotopic dating of illite-rich size fractions remains a valuable method in stratigraphic and phenomenological dating of sedimentary rock sequences that underwent varied evolutionary processes including burial diagenesis, contact and regional metamorphism, continental weathering, tectonic folding/faulting, or any tectonic impact on ore deposits (e.g., [1]). In fact, if the interpretation of the data improved only slightly since the early studies [2-4], constraining the analytical aspects improved significantly the selection and interpretation of the "ages". However, despite many successful applications over the years, not all studies on illite separates provided reliable isotopic ages. The reasons for such failures were due often to natural environmental conditions that might have rendered the identification of illite authigenesis that describes its in situ crystallization and growth in sedimentary 
rock matrices. More unexpectedly, such misleading attempts could also result from sample preparation, as formulated quite long ago (e.g., [5]). Not often taken into account, this "technical" aspect will be discussed again hereunder, on the basis of a regional example.

Theoretically, any selected size fraction of a sedimentary rock needs to consist of pure, authigenic and mono-generational illite-type crystals, which are therefore clean of illite with multiple origins and of other contaminating K-carriers to yield reliable isotopic ages (e.g., discussion in [6]). Separation of pure authigenic illite fractions remains a determining step in any isotopic dating attempt, which needs to be supported by morphological, mineralogical, crystallographic and geochemical information for an appropriate interpretation of the obtained isotopic database. In turn, when separation at any size of any kind of host-rock type does not provide pure illite fractions, the relative amounts of authigenic and "contaminating" K-carriers need to be reconsidered in the selected size fractions. The isotopic age of the authigenic component needs then to be recalculated on the basis of their respective ages and the contents of the two components in the various fractions [7].

The contribution presented hereunder does not highlight new results but intends to discuss how to improve steps of the analytical procedure to identify and select best the authigenic mineral separates. The presentation of these technical aspects will also briefly recall the successive improvements that were applied to the clay-mineral preparation over the years, to highlight their importance. The recollection is based on an example of illite-rich separates from barren and uranium-bearing rocks of the Dominique Peter deposit in the Carswell structure of the Saskatchewan Basin in Canada.

\section{The Improving Steps in the Sample Preparation of Illite-Rich Fractions}

As is the case for any isotopic-dating procedure, K-Ar dating of clay-sized materials is based on the fact that the constitutive clay minerals of separated size fractions are authigenic (meaning newly formed) in the host rocks and also do not lose radiogenic ${ }^{40} \mathrm{Ar}$ because of their small size. Despite being demonstrated repetitively since the 1970s on $<2 \mu \mathrm{m}$ size fractions (e.g., [8]), and more recently on isolated nanometer-sized illite crystals (e.g., [9]), the important prerequisite of radiogenic ${ }^{40} \mathrm{Ar}$ retention is still debated on the basis of mathematical models that favor a mechanical release of radiogenic ${ }^{40} \mathrm{Ar}$ from illite crystals when they decrease in size. Such a premise is clearly not satisfying, as it does not, for instance, take into account the fact that $<0.02 \mu \mathrm{m}$ nanometer-sized illite crystals of bentonite beds that are basically devoid of any detrital contribution due to their volcanic origin, were found to be older sometimes (and not younger) than their corresponding coarser separates [9]. In summary, not denying that age decreases can result from radiogenic Ar loss, but not because of the crystal size decrease, an obvious interpretation for decreasing K-Ar ages of progressively smaller clay particles is due to an increased content of authigenic particles. No other analytical reality exists for apparent age reductions in mineral mixtures consisting of mixed authigenic and detrital or earlier crystallized illite particles (e.g, [10]).

In addition to this debated behavior in radiogenic ${ }^{40} \mathrm{Ar}$ retention potentials of microto-nanometer-sized illite particles, a technical aspect had deleterious effects on the results of the pioneering and of later K-Ar dating studies, namely the used disaggregation technique of the host rocks. Indeed, the generally, if not the only, used technique at the early times of application isotopic dating on clay materials was based on crushing the soft rocks, as were and still are the igneous and metamorphic rocks. The negative impact of this technique on the mineral compositions of the small-size separates started to be suspected in the mid-1980s, because such crushing produces also a size decrease in the coarse minerals into that of clay-sized particles. Such "mechanical" size reduction notably modifies the mineral composition of the real clay materials by generating small fragments of the whole-rock-constituting coarse minerals. Any addition of fragments of such components contaminates the K-Ar ages of the original authigenic crystals by increasing their true amounts of radiogenic ${ }^{40} \mathrm{Ar}$ and radioactive $\mathrm{K}$ [11]. Such mixtures were reported, discussed and explained in varied studies (e.g, [12-14]), which sets the rock disaggregation and size fractionation as a more challenging technical step than is generally considered, even if it is now part of a routine preparation. The crushing method 
was replaced by a freeze-thawing technique [11], whereas an experiment based on high-voltage disaggregation was tested recently [15]. It has also been shown recently in studies with the separation of clay materials down to nanometer sizes that a careful, but not a necessarily easy, method promoted by [16] allows the separation and distinction of nucleating illite crystals that grow progressively in interlayered illite-smectite particles [17], and also allows their isotopic dating by various methods $[9,18]$. This concept was tested initially by K-Ar dating of illite-rich crystals of bentonite units that were selected at the time because they are lacking detrital minerals, and later on nanometer-sized illite-rich crystals of sandstones (e.g., [19-21]). Such results on extra-small crystals focus even more on the importance of the separation procedure applied to clay populations of sedimentary to meta-sedimentary rocks.

In turn, an appropriate separation technique of clay-rich micro- to nanometer sized fractions is mandatory in isotopic dating of clay components from sedimentary to meta-sedimentary rocks and needs to be combined with a precise identification of the separated mineral contents. However, it might not be always sufficient for successful interpretations, as will be discussed on the basis of a study on previous K-Ar dating of Precambrian U host-rocks by [22], when clay separates were essentially studied at the unique $<2 \mu \mathrm{m}$ size. Since the K-Ar ages published at that time were difficult to interpret, some additional K-Ar ages were completed recently on smaller $(<0.2 \mu \mathrm{m})$ fractions to find out if size fractionation can be a supportive aspect in the interpretation of isotopic data of clay minerals. In turn, the goal of the present review was also to constrain further the available K-Ar geochronological database of the Dominique Peter U deposit (Figure 1A,B).

It is probably appropriate to recall also that any K-Ar dating attempt of size separates consisting of illite-type materials outlines as many "data" as analyzed size fractions, which should not be considered as "ages" at that time. The step from "data" to "age" needs to evaluate the isotopic results, for instance with the Harper [23] and the classical isochron ${ }^{40} \mathrm{Ar} /{ }^{36} \mathrm{Ar}$ vs. ${ }^{40} \mathrm{~K} /{ }^{36} \mathrm{Ar}$ patterns. Then, the strictly isotopic interpretation needs to be compared to the mineralogical, geochemical, morphological and geological results to synthesize a consistent age interpretation. In summary, many K-Ar data of clay minerals give only a few coherent ages, which depend on the analytical measurements, but also on the sample preparation and separation, as well as on the historical evolution of the host rocks.

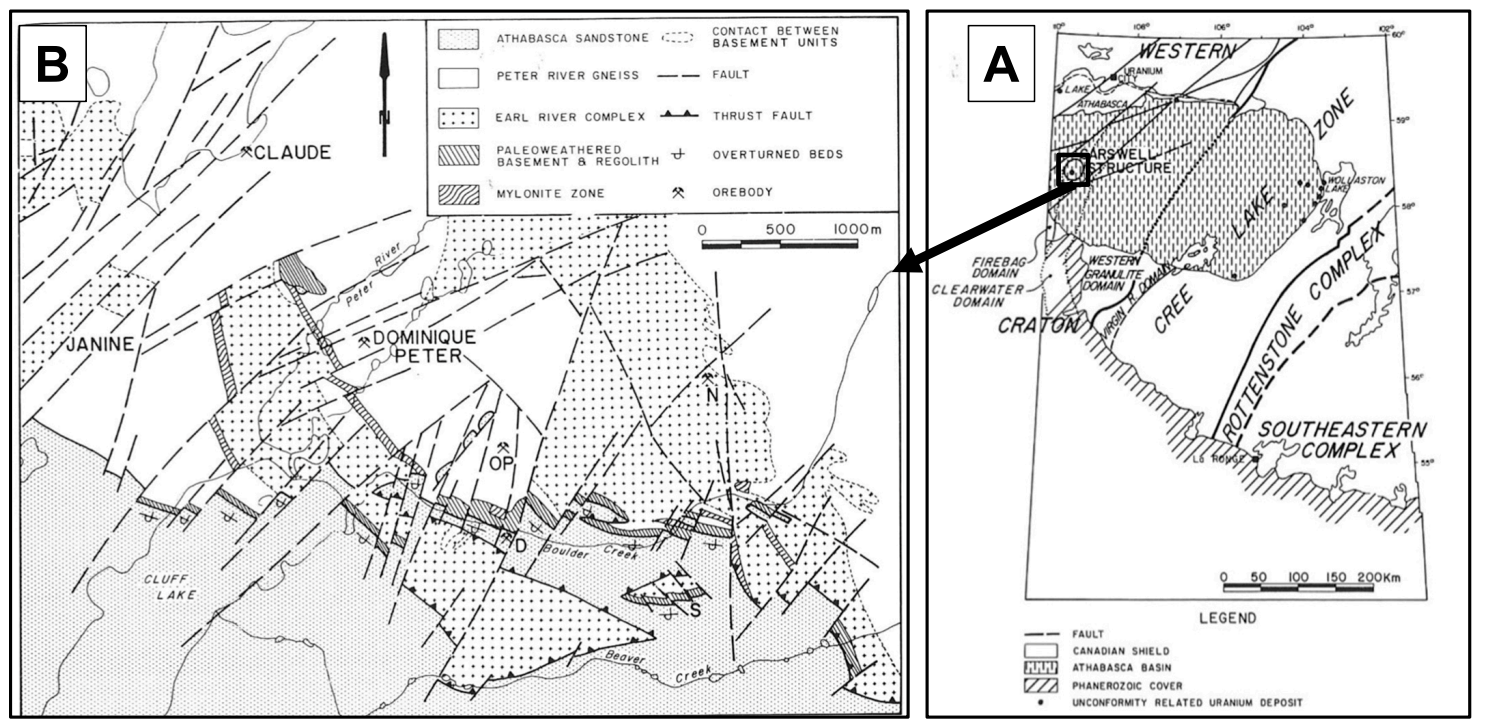

Figure 1. (A) Location of the Carswell structure in the Athabasca Basin (modified from [24]); (B) Blow up on the Dominique Peter ore deposit in the Carswell structure (modified from Bruneton [25]).

\section{The Available Regional Geochronological and Tectonic-Thermal Information}

The unconformity between the low-Proterozoic basement and the mid-Proterozoic sandstones of the Athabasca Basin in northern Saskatchewan (Canada) hosts many U deposits that are classified as "unconformity-types", being characterized by high concentrations of high-grade U. Most of these U 
deposits, such as those of Key Lake, Rabbit Lake, Collins Bay, Cigar Lake, Midwest Lake, Eagle Point or McArthur River, are from the eastern area of the basin, while fewer deposits were discovered in the western area that includes the circular Carswell structure and the Shea Creek deposit located about $15 \mathrm{~km}$ to the south of the deposit studied here (Figure 1A).

Before screening the available isotopic ages of the $U$ deposits and the illite separates from associated barren tocks, it should be recalled that the errors of the different published ages, whatever the used isotopic method and the analyzed materials, are given at the $2 \sigma$ level. The U-Pb isotopic studies of $\mathrm{U}$ deposits from eastern Saskatchewan Basin yield a primary mineralization at 1350-1300 Ma with an older age at $1514 \pm 18 \mathrm{Ma}$ for the McArthur ore [22,26-31]. In the Carswell structure, the main mineralizing event is generally considered to be at $\sim 1100 \mathrm{Ma}$, again on the basis of U-Pb isotopic studies [32-34]. Alternatively, Clauer et al. [35] and recently Laverret et al. [36] obtained older K-Ar ages up to $1453 \pm 2 \mathrm{Ma}$ for illite-rich size fractions of the altered basement and the sedimentary cover at the nearby Cluff Lake and Shea Creek discoveries, but never on clay minerals of ore-bearing rocks. At the same time, Bell [34] published an age of 1300 Ma for the Numac mineralization of the Carswell structure, on the basis of three debatable U-Pb results, two of them plotted above the Concordia curve.

It is still not clear from these geographically widely dispersed geochronological records if the six successive mineralizing events claimed by Cumming and Kristic [30] at 1515, 1350, 1280, 1000, 575 and $225 \mathrm{Ma}$ on the basis of $\mathrm{U}-\mathrm{Pb}$ ages from over the entire basin were systematically involved in the evolution of all studied $\mathrm{U}$ ores. It is also not yet clear whether the K-Ar dating of illite that crystallized during some of these hydrothermal events in the basement and/or in the sedimentary cover can be considered as supportive for the deposition of nearby $U$ ore minerals, even if shown elsewhere [37] and advocated locally by [35]. In the same context of age comparisons, the question of the 200-Ma age gap between the ages determined for $\mathrm{U}$ genesis in the eastern and southwestern Athabasca Basin remains to be addressed.

Philippe et al. [22] combined U-Pb and $\mathrm{Pb}-\mathrm{Pb}$ age systematics on different types of U-hosting rocks from the Carswell structure, together with K-Ar dating of clay materials from associated barren metasediments. They defined four successive episodes starting with a retromorphosis of the basement during the Hudsonian orogeny at 1780 Ma followed by an initial crystallization of uraninite at $1341 \pm 17 \mathrm{Ma}$. The K-Ar ages obtained on the associated illite fractions of U-host and barren rocks gathered at $1447 \pm 45 \mathrm{Ma}, 1282 \pm 40 \mathrm{Ma}$ and $1184 \pm 15 \mathrm{Ma}$. Characterized by a Fe-kaolinite/Fe-illite paragenesis, the next event occurred at $~ 900 \mathrm{Ma}$, whereas the final one corresponds to a local remobilization of uranium at $\sim 325 \mathrm{Ma}$. This last episode was considered as a late alteration that induced an intense coffinitization, as was the case in ore concentrations of other metalliferous regions [38].

Alexandre et al. [39] completed the regional dating aspects by an evaluation of the basinal evolution, pointing to the important epoch between about 1750 and 1600 Ma that concentrated the determining conditions for the formation of unconformity conditions for the $U$ deposits. Those authors also evaluated the thermal conditions during the different events at Rabbit Lake, Dawn Lake and McArthur River, where: (1) the initial illitization developed at about $230^{\circ} \mathrm{C}$, (2) the ore-forming event accompanied by coarse-grained illite developed at a near temperature of $240{ }^{\circ} \mathrm{C}$, (3) a further alteration with dravite precipitation as well of various metal sulfides occurred at about $135^{\circ} \mathrm{C}$, and (4) a late alteration step with kaolinite precipitation and Fe hydroxide developed at about $50^{\circ} \mathrm{C}$ [40]. The same authors showed also that basinal fluids circulated over long distances and interacted with the rock matrices during the initial illitization and during the alteration episode after $\mathrm{U}$ deposition.

\section{The Geological Setting}

The Carswell circular structure consists of outer and inner rings made of diagenetic to anchi-metamorphic deformed metasediments, and of a central crystalline basement core that belongs to the Western Craton of the Churchill Province (Figure 1A; [24]). In its southern area, where the metals are concentrated, the basement consists mostly of the Earl River complex containing intercalated 
quartz-feldspar and mafic gneisses with subordinate amphibolites. No Archean ages were reported in the entire region, whereas the Hudsonian metamorphic climax was dated at $1900 \mathrm{Ma}$ by the Sm-Nd and $\mathrm{Pb}-\mathrm{Pb}$ methods [41]. The structural setting consists of a basement surrounded by sandstones of the Athabasca Group that were dated at $\sim 1700 \mathrm{Ma}$ by the U-Pb method on constitutive apatite [42]. Mafic dykes were also dated at 1300 and $1100 \mathrm{Ma}$ by Rb-Sr whole-rock isochrons in the eastern basin [43].

The origin of the Carswell circular structure has been debated for long, especially its formation time (Figure 1B). Considered to represent a meteoritic impact (e.g., [44]), its formation age was difficult to constrain: Wanless et al. [45] published a K-Ar age of $485 \pm 50 \mathrm{Ma}$ for local breccia, whereas ${ }^{40} \mathrm{Ar} /{ }^{39} \mathrm{Ar}$ laser-fusion analyses of aphanitic material extracted from similar breccia-types provided results scattered between $\sim 515$ and $365 \mathrm{Ma}$, most values ranging from 515 to $415 \mathrm{Ma}$ [34]. Bottomley et al. [46] reported even a ${ }^{40} \mathrm{Ar} /{ }^{39} \mathrm{Ar}$ plateau age of $\sim 115 \mathrm{Ma}$ on an impact-melted rock. In summary, these scattered results render delicate any combination of heteroclite data, (add a comma) obtained by different methods on various materials.

There are also minor U occurrences in pegmatoids from the Carswell structure that were attributed to anatectic processes during the Hudsonian orogeny [47,48]. Among the deposits located to the south of the structure, the Cluff D site is the only one occurring in Athabasca sandstones next to the unconformity. The other U concentrations, such as those of the close Claude and Dominique Peter deposits, are located in the basement where they are spatially controlled by Hudsonian or Late Hudsonian tectonic structures [49].

\section{The Sample Description and the Analytical Procedure}

Fourteen core samples of two drillings (1433 and 1607) into Dominique-Peter metasediments with economic U contents were selected and analyzed in the initial publication of Philippe et al. [22]. Due to their highly indurated state, the whole rocks could not be disaggregated by the only available freeze-thaw method and were crushed gently after a wash of the drill cores with deionized water. The crushing was kept as short as possible to avoid an over-crushing of the coarse constitutive K-rich minerals. Once crushed, the rock powder was poured into deionized water and left to settle to recover the $<2 \mu \mathrm{m}$ size fractions following the classical Stoke's law. The recovered slurries were X-rayed (XRD) for their mineral composition. Three of the initial samples were selected again for a further grain-size fractionation at the $<0.2 \mu \mathrm{m}$ level. Obtained after a preparation identical to the initial one, and a super-centrifugation of the $<2 \mu \mathrm{m}$ fractions, these new analyses were undertaken to collect more information about the origin of the analyzed illite mineral, and therefore to control the initial K-Ar database and consolidate the epochs of the successive tectonic-thermal events occurring in and around the Dominique Peter U deposit.

Argon was extracted from separated $<2$ and $<0.2 \mu \mathrm{m}$ size fractions in a glass line connected to the mass spectrometer, following a technique close to that of [50]. The powder separates were preheated under vacuum at $100{ }^{\circ} \mathrm{C}$ directly in the extraction line overnight to lower the amount of atmospheric Ar adsorbed on the particles during separation, handling and preparation of the size fractions. The reproducibility of the initial Ar extractions was periodically tested by six analyses of the standard glauconite-Odin (GL-O) during the first study, that gave an average of $24.14 \pm 0.22 \times$ $10^{-6} \mathrm{~cm}^{3} / \mathrm{g}$ radiogenic ${ }^{40} \mathrm{Ar}$ in the Standard Temperature and Pressure (STP) system, which is slightly below the theoretical value of $24.85 \pm 0.24 \times 10^{-6} \mathrm{~cm}^{3} / \mathrm{g}$ [51]. The ratio of the atmospheric ${ }^{40} \mathrm{Ar} /{ }^{36} \mathrm{Ar}$ ratio was also determined periodically during both analytical episodes to control the accuracy of the mass spectrometer. The following values were obtained: $299.4 \pm 4.1$ for four measurements during the first round and $296.5 \pm 0.2$ for one determination during the recent one, the theoretical value being set at $298.6 \pm 0.4$ [52]. The Ar isotopic abundances were calculated using a ${ }^{38} \mathrm{Ar}$ tracer, while the $\mathrm{K}_{2} \mathrm{O}$ concentrations were obtained by flame spectrophotometry with an accuracy of $\pm 1.5 \%(2 \sigma)$. The ages were calculated with the usual decay constants [53] with and an overall reproducibility of about $\pm 2.5 \%(2 \sigma)$. 


\section{The Results}

The $<2 \mu \mathrm{m}$ size fractions of the fourteen samples studied by [22] consisted of $55 \pm 25 \%$ illite and $45 \pm 25 \%$ chlorite (Table 1). Kaolinite was detected in three samples from the upper part of the drilling 1607. Illite occurred commonly as the $1 \mathrm{M}$ and $1 \mathrm{Md}$ polytypes, which all qualify for low-temperature crystallization conditions. The Full Width at Half Maximum (FWHM) that numerates the width of the $10 \AA$ (001) XRD peak of illite at half of its height usually provides a fair estimate of the expandability of the analyzed illite. Also used often to evaluate randomly the temperature at which the studied minerals were subjected, it can be agreed that FWHM data higher than 0.42 characterize a diagenetic impact, while those between 0.42 and 0.25 are specific to anchizonal conditions, and that those below 0.25 identify an epizonal impact [54,55]. Merriman and Frey [56] suggested a temperature range below $200{ }^{\circ} \mathrm{C}$ for the anhizonal stage, an epizonal stage above $250{ }^{\circ} \mathrm{C}$ and diagenetic conditions below $150{ }^{\circ} \mathrm{C}$. The commonly used FWHM depends also on the size of the analyzed particles and on the lattice strain [57-59]. Here, most of the already-analyzed $<2 \mu \mathrm{m}$ size fractions yielded FWHM values that suggest a diagenetic stage with values above 0.42, except for those of the samples 19 to 21 from upper part of the drilling 1607 . These values also outline slightly stronger anchizonal conditions, unless they consist of two types or two generations of illite crystals. Estimated to be below $200{ }^{\circ} \mathrm{C}$, the crystallization temperature appears to be quite low to impact noticeably the indurated gneissic basement.

Table 1. X-ray data of the previously studied $<2 \mu \mathrm{m}$ by Philippe et al. [22] and of the $<0.2 \mu \mathrm{m}$ illite-rich size fractions analyzed herein.

\begin{tabular}{|c|c|c|c|c|c|c|}
\hline Samples & Depth & Illite & Chlorite & Kaolinite & FWHM & Remarks \\
\hline IDs & (m) & $(\%)$ & $(\%)$ & $(\%)$ & & \\
\hline \multicolumn{7}{|c|}{ Fractions $<2 \mathrm{~m}$} \\
\hline \multicolumn{7}{|c|}{ Drill hole 1607} \\
\hline $81-19$ & 181 & 67 & 13 & 20 & 0.28 & \\
\hline $81-20$ & 204.5 & 65 & 15 & 20 & 0.27 & \\
\hline $81-21$ & 251 & 55 & 24 & 21 & 0.32 & \\
\hline $81-22$ & 260 & 53 & 47 & & 0.55 & Al-chlorite \\
\hline $81-26$ & 294 & 75 & 25 & & 0.42 & 1Md illite + Al-chlorite \\
\hline $81-30$ & 321 & 50 & 50 & & 0.56 & 1Md illite + Al-chlorite \\
\hline $81-32$ & 411 & 55 & 45 & & 0.66 & 1Md illite + Al-chlorite \\
\hline $81-34$ & 427.5 & 48 & 52 & & 0.50 & $1 \mathrm{Md}$ illite $+\mathrm{Al}$-chlorite \\
\hline $81-37$ & 461 & 53 & 40 & $?$ & 0.59 & 1Md illite + Al-chlorite \\
\hline $81-40$ & 476 & 83 & 17 & & 0.59 & $1 \mathrm{M}$ illite + Al-chlorite \\
\hline \multicolumn{7}{|l|}{ Drill hole 1433} \\
\hline $81-48$ & 590 & 61 & 39 & & 0.50 & cis-1M illite + Al-chlorite \\
\hline $81-49$ & 596.5 & 77 & 23 & & 0.43 & $\begin{array}{c}\text { cis-1M illite }+1 \mathrm{Md} \text { illite }+ \\
\text { Al-chlorite }\end{array}$ \\
\hline $81-50$ & 608 & 66 & 34 & & 0.48 & cis-1M illite + Al-chlorite \\
\hline $81-51$ & 610 & 75 & 25 & & 0.52 & 1Md illite + Al-chlorite \\
\hline \multicolumn{7}{|c|}{ Fractions $<0.2 \mu \mathrm{m}$} \\
\hline \multicolumn{7}{|c|}{ Drill hole 1607} \\
\hline $81-40$ & 476 & 73 & 27 & & & \\
\hline \multicolumn{7}{|l|}{ Drill hole 1433} \\
\hline $81-48$ & 590 & 60 & 40 & & & \\
\hline $81-49$ & 608 & 78 & 22 & & & \\
\hline
\end{tabular}

No relationship could be detected between the K-Ar ages of the extracted size fractions and their mineral compositions. However, links between the K-Ar ages and some chemical and petrographic characteristics of the host rocks can be mentioned. For instance, the size fractions of the slightly altered gneisses from drill-hole 1607 contain some kaolinite (samples 19, 20, 21) and yield quite narrow K-Ar data, ranging from $1498 \pm 33$ to $1402 \pm 32$ Ma (Table 2). Similar ages were obtained for the samples 22 and 26 of the same type of rocks, however without chlorite. All these gneisses yield amounts of U below $4 \mathrm{\mu g} / \mathrm{g}$ of rock. Alternatively to these rocks, mylonitized gneisses (samples 30, 32, 34, and 37) contain 
clay fractions with younger K-Ar data between $1322 \pm 29$ and $1242 \pm 27 \mathrm{Ma}$, and are characterized by higher $\mathrm{U}$ contents between 10 and $20 \mu \mathrm{g} / \mathrm{g}$ of $\mathrm{U}$, except for sample 34 . The sample 40 with a significantly younger K-Ar data of $1020 \pm 22 \mathrm{Ma}$ for its $<2 \mu \mathrm{m}$ size fraction is located about $3 \mathrm{~m}$ away from a U-rich zone, with positive anomalies in $\mathrm{Pb}, \mathrm{Cu}$ and Mo. In drill-hole 1433, K-Ar data of $1311 \pm 28$ and $1283 \pm 28$ Ma were determined for the clay fraction of two deeply weathered and serpentinitized ultramafic rocks, also characterized by green nickel concentrations (= garnierite) that occur as pockets and veins. The two samples 48 and 49 contain 740 and $17 \mu \mathrm{g} / \mathrm{g}$ of $\mathrm{U}$, respectively. Characterized by quartz enrichments, the gneiss samples 50 and 51 contain $U$ concentrations below $3.5 \mu \mathrm{g} / \mathrm{g}$, but high $\mathrm{Pb}$ concentrations of 500 and $390 \mu \mathrm{g} / \mathrm{g}$, and clay fractions with significantly younger K-Ar data at $1199 \pm 26$ and $1169 \pm 26 \mathrm{Ma}$. In summary, all these samples appear to have been structurally and thermally impacted by events that altered their metal contents and, more specifically, their U contents and isotopic equilibria. In turn, it depends also on how these events altered the isotopic systems of other non-metalliferous mineral or rock types.

Table 2. K-Ar data of the previously studied $<2 \mu \mathrm{m}$ by Philippe et al. [22] and of the $<0.2 \mu \mathrm{m}$ illite-rich size fractions herein analyzed.

\begin{tabular}{|c|c|c|c|c|c|c|}
\hline Sample & $\mathrm{K}_{2} \mathrm{O}$ & ${ }^{40} \mathrm{Ar}{ }^{*}$ & ${ }^{40} \mathrm{Ar}{ }^{*}$ & ${ }^{40} \mathrm{~K} /{ }^{36} \mathrm{Ar}$ & ${ }^{40} \mathrm{Ar} /{ }^{36} \mathrm{Ar}$ & Age \\
\hline IDs & $(\%)$ & $(\%)$ & $\left(10^{-6} \mathrm{~cm}^{3} / \mathrm{g}\right)$ & & & $(\mathrm{Ma} \pm 2 \sigma)$ \\
\hline \multicolumn{7}{|c|}{ Fractions $<2 \mu \mathrm{m}$} \\
\hline \multicolumn{7}{|c|}{ Drill hole 1607} \\
\hline $81-19$ & 4.48 & 98.67 & 324.6 & 0.164 & 22,138 & $1460(31)$ \\
\hline $81-20$ & 4.53 & 98.47 & 340.9 & 0.138 & 19,322 & $1498(33)$ \\
\hline $81-21$ & 3.77 & 97.46 & 257.5 & 0.108 & 13,788 & $1402(32)$ \\
\hline $81-22$ & 3.66 & 98.03 & 261.4 & 0.113 & 15,011 & $1446(30)$ \\
\hline $81-26$ & 4.94 & 98.99 & 341.1 & 0.228 & 29,387 & $1412(31)$ \\
\hline $81-30$ & 3.67 & 98.56 & 214.6 & 0.189 & 20,571 & $1256(29)$ \\
\hline $81-32$ & 3.96 & 98.66 & 230.6 & 0.204 & 22,072 & $1252(28)$ \\
\hline $81-34$ & 4.24 & 98.47 & 244.3 & 0.180 & 19,271 & $1242(28)$ \\
\hline $81-37$ & 3.91 & 98.48 & 245.6 & 0.166 & 19,399 & $1322(30)$ \\
\hline $81-40$ & 7.29 & 98.54 & 322.3 & 0.246 & 20,247 & $1020(22)$ \\
\hline \multicolumn{7}{|l|}{ Drill hole 1433} \\
\hline $81-48$ & 4.83 & 98.59 & 291.0 & 0.187 & 20,933 & $1283(28)$ \\
\hline $81-49$ & 5.93 & 99.07 & 368.1 & 0.274 & 31,758 & $1311(28)$ \\
\hline $81-50$ & 4.62 & 97.62 & 244.9 & 0.125 & 12,415 & $1169(26)$ \\
\hline $81-51$ & 6.04 & 98.15 & 331.5 & 0.156 & 15,985 & $1199(26)$ \\
\hline \multicolumn{7}{|c|}{ Fractions $<0.2 \mu \mathrm{m}$} \\
\hline \multicolumn{7}{|c|}{ Drill hole 1607} \\
\hline $81-40$ & 6.35 & 99.30 & 246.3 & 0.620 & 43,650 & $922(22)$ \\
\hline \multicolumn{7}{|l|}{ Drill hole 1433} \\
\hline $81-48$ & 4.79 & 98.20 & 202.0 & 0.220 & 17,010 & $983(23)$ \\
\hline $81-49$ & 6.05 & 98.60 & 229.5 & 0.312 & 21,640 & $906(21)$ \\
\hline
\end{tabular}

The $<0.2 \mu \mathrm{m}$ size fractions of the samples 40,48 and 49 yield similar mineral compositions, with $69 \pm 9 \%$ illite and $31 \pm 9 \%$ chlorite. Their K-Ar data are either slightly or significantly lower between $983 \pm 23$ and $906 \pm 21 \mathrm{Ma}$, than those of their corresponding $<2 \mu \mathrm{m}$ fractions (Table 2). These new $\mathrm{K}$-Ar values raise two concerns: (1) some of the $<2 \mu \mathrm{m}$ size fractions yield $\mathrm{K}$-Ar age values that are significantly higher than those of the $<0.2 \mu \mathrm{m}$ fractions and, therefore, most probably contain mixtures of two types or two generations of illite, and (2) the lower K-Ar age obtained previously at about $1000 \mathrm{Ma}$ appears to be more significant than expected. In turn, some of the previously published $\mathrm{K}$-Ar ages of the $<2 \mu \mathrm{m}$ separates appear now to have been biased by the addition of older illite type particles.

Before starting a discussion about these age differences, the completed K-Ar database will be evaluated again by plotting the individual data values into a Harper [23] diagram that combines the 
amounts of radiogenic ${ }^{40} \mathrm{Ar}$ and $\mathrm{K}_{2} \mathrm{O}$, and in an isochron diagram that compares the ${ }^{40} \mathrm{Ar} /{ }^{36} \mathrm{Ar}$ and ${ }^{40} \mathrm{~K} /{ }^{36}$ Ar ratios. Both correlations are reliable controls of the relationships among the $\mathrm{K}$ and Ar contents of clay separates. If all samples with identical ages fit lines that either intersect the coordinates at their origins for the former diagram, or at an initial ${ }^{40} \mathrm{Ar} /{ }^{36} \mathrm{Ar}$ ratio near 300 , which is the value of the atmospheric Ar in the isochron display, these lines can reasonable be considered as isochrons. Alternatively, if a line through several data points yields initial ${ }^{40} \mathrm{Ar} /{ }^{36} \mathrm{Ar}$ ratios significantly away from atmospheric value or radiogenic ${ }^{40} \mathrm{Ar}$ contents far away from intersection of the two coordinates, these sample fractions necessarily contain mixtures of heterogeneous minerals and the data lines cannot be representative of isotopic "ages". Here, the analyzed size fractions plot on three alignments in an isochron diagram (Figure 2B): (1) an upper line through the data points of the size fractions 19, 20, 21, 22 and 26, which intersects the abscissa at $\sim 300$ and can, therefore, be considered to be an isochron with an age of $1448 \pm 48 \mathrm{Ma}$; (2) a sub-parallel line consisting of the data points from size fractions 32 , $34,48,49,50$ and 51, that yields a negative intersect on the ${ }^{40} \mathrm{Ar} /{ }^{36} \mathrm{Ar}$ abscissa, and consequently is not an isochron; and (3) a line with a lower slope that intersects the abscissa again at $~ 300$, again with a $\mathrm{K}$-Ar age of $937 \pm 39 \mathrm{Ma}$ and the characteristics of an isochron. The Harper [23] plot provides a slightly different information (Figure 2A): the line with the flattest slope through the three points of the $<0.2$ $\mu \mathrm{m}$ size fractions crosses the intersection of the two coordinates, confirming that the contents of the radioactive and radiogenic isotopes are consistently correlated. The two lines with initials far from the intersection of the two coordinates fit mostly through the $<2 \mu \mathrm{m}$ fractions of the samples from 1433 drilling cores, which implies heterogeneous relationships between the radiogenic ${ }^{40} \mathrm{Ar}$ and $\mathrm{K}_{2} \mathrm{O}$ contents. The last line through the data points of the upper $<2 \mu \mathrm{m}$ fractions of drill hole 1607 also fits both coordinates, suggesting a second homogeneous relation between radiogenic ${ }^{40} \mathrm{Ar}$ and $\mathrm{K}_{2} \mathrm{O}$.
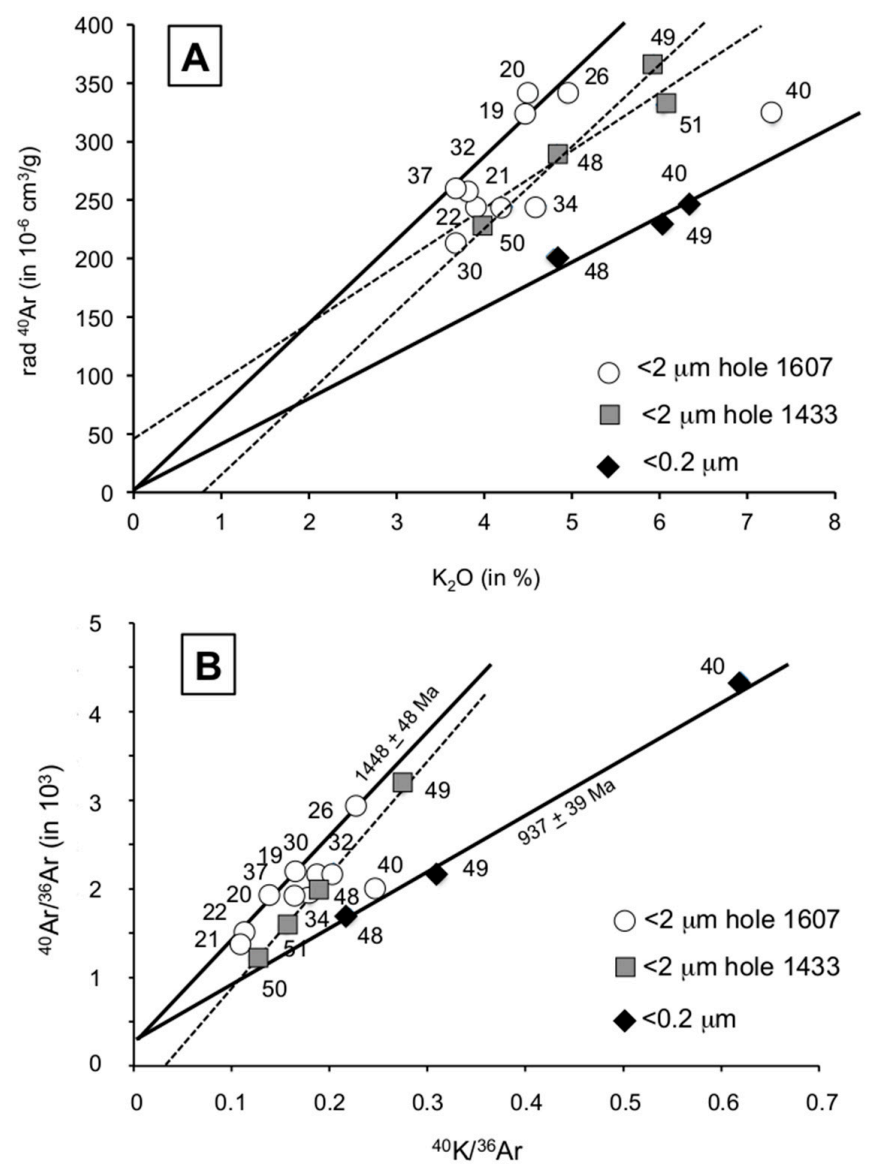

Figure 2. (A) Harper [23] pattern and (B) isochron diagram of the previously studied $<2$ and the herein analyzed $<0.2 \mu \mathrm{m}$ illite-rich size fractions. 
In summary, the K-Ar data point towards an older K-Ar age of $1458 \pm 48 \mathrm{Ma}$ and a younger age of $937 \pm 39 \mathrm{Ma}$, with data points dispersed in between the two isochrons that correspond to mixed illite particles with different origins and/or ages.

\section{Discussion}

\subsection{How to Sort out K-Ar Illite Ages}

The results of the three $<0.2 \mu \mathrm{m}$ fractions modify the conclusions of Philippe et al. [22] by invalidating two of the initially published K-Ar ages. In fact, the data consisting of individual values from $\sim 1320$ to $1170 \mathrm{Ma}$ seem to result from mixed illite populations of two generations. This central group of ages corresponds to illite-rich fractions of highly indurated mylonitized gneisses, nickel-mineralized garnerites and quartz-enriched gneisses. These rock-types were assigned to a tectonic-metamorphic event that significantly altered the major $U$ deposits of the region [49] with an age based on a mean value near the $1270 \pm 25$ Ma obtained on similar samples from D deposit [35]. In fact, the large uncertainties of the results incited to combine events that were obviously not related.

The older K-Ar ages of the size fractions separated from slightly altered gneisses with a mean of $1458 \pm 48$ Ma remain identical to that of Philippe et al.'s [22] publication. Such a mean age was also obtained on clay minerals from basement rocks in the vicinity of the D deposit [35], which also favored the comparison. On the other hand, the mean age at $937 \pm 39 \mathrm{Ma}$ for the K-Ar ages of the $<0.2 \mu \mathrm{m}$ fractions from samples 40,48 and 49 , together with the slightly older $<2 \mu \mathrm{m}$ of sample 40 , consolidates the reality of a tectonic-thermal episode at that time in the district.

\subsection{Some Adjustments of the Regional Interpretation due to the New Illite K-Ar ages}

K-Ar dated by Laverret et al. [36], illite from nearby Shea Creek district was extracted from the sandstone cover and the underlying structured basement. In fact, the K-phyllo-silicates of the structured basement should be identified as micas or sericite rather than illite because of the more intense imprint by the structural event. In this district, most samples belong to the Anne ore deposit with structural, petrographic and geochemical characteristics reported before [60-62]. In the barren areas away from $\mathrm{U}$ concentrations, illite/sericite was mainly occurring in the cis-vacant $1 \mathrm{M}$ polymorphic type as coarse-grained lath-shaped particles, and as fine-grained particles of the trans-vacant $1 \mathrm{M}$ polytype next to and in the U-mineralized strata. These U-rich strata were U-Pb-dated and compared to the primary mineralization at $1350-1300 \mathrm{Ma}$ and between 1330 and $1275 \mathrm{Ma}$ in the Shea Creek prospect (e.g., [63]). The age average at 1330-1350 Ma appears, then, as a milestone in the regional metalliferous evolution. In the eastern basin, mafic dykes were also dated at $1300-\mathrm{Ma}$ by $\mathrm{Rb}-\mathrm{Sr}$ whole-rock isochrons [43]. The tectonically induced hydrothermal system favoring illite crystallization was found to be multi-episodic at $1453 \pm 2 \mathrm{Ma}$ and at $1330 \pm 20 \mathrm{Ma}$ in the Dominique Peter district. On the other hand, the tectonic-thermal episode that was considered previously as having induced illite crystallization at $~ 1235 \mathrm{Ma}$ seems to no longer have occurred. In detail, the K-Ar results were grouped into: (1) a K-Ar age of $1308 \pm 5$ Ma for illite from barren host rocks; (2) K-Ar ages of $1453 \pm 2$ and $1330 \pm 20 \mathrm{Ma}$ for illite of the inner-halo sandstones and of the associated basement rocks, this latter age being questioned by the K-Ar data obtained here; (3) two K-Ar ages of $1455 \pm 9$ Ma and of a much less constrained $1234 \pm 18 \mathrm{Ma}$ age for illite (mica)-rich size fractions of the altered basement; and (4) size fractions of the outer halos of the sandstones consisting of mixtures of two generations of illite particles of approximately 1450 and $1330 \mathrm{Ma}$.

No clear relationship was found between the illite polymorphic types and their crystallization ages, meaning that the crystallization into the cis-vacant and/or the trans-vacant polytype did not relate to a specific event but, more probably to the changing physical and chemical crystallization conditions during the successive tectonic-thermal episodes. Contemporaneous illite polytypes seem to depend on an increased distance to the $U$ deposit, possibly resulting from a progressively lower crystallization temperature and a decreasing fluid circulation. A plausible scenario suggests crystallization of the 
cis-vacant $1 \mathrm{M}$ illite polytype from chemically different environments, at a lower temperature and away from $U$ concentrations, instead of the equivalent trans-vacant $1 \mathrm{M}$ polytype detected next to the $\mathrm{U}$ ores, both precipitating contemporaneously within analytical uncertainty. In summary, illite crystallization in the Dominique Peter district seems to have been induced by the events at $1448 \pm 48$ and $937 \pm 39 \mathrm{Ma}$. The first of these two ages is close to the oldest $\mathrm{U}-\mathrm{Pb}$ ages of the uraninite from nearby Cluff Lake deposit [22]. The younger K-Ar age of $937 \pm 39 \mathrm{Ma}$ is within analytical uncertainty, with the $945 \pm 50 \mathrm{Ma}$ age, also from nearby Cluff Lake deposit [35]. The fact that the $1330 \pm 20 \mathrm{Ma}$ data seems to result from an analytical uncertainty due to an erratic mixing of two illite generations collected away from $U$ concentrations suggests a variable resistance of the highly indurated rocks to the successive thermal events.

The illite-forming tectonic-thermal events dated by K-Ar may have occurred contemporaneously to, but obviously not systematically with those inducing the deposition of the associated U oxides, which were dated independently by the $\mathrm{U}-\mathrm{Pb}$ method in the entire Athabasca Basin. The U-Pb dating of $U$ oxides of the Shea Creek prospect provided two distinct ages at $\sim 1330$ and $\sim 1275 \mathrm{Ma}$ for U oxides [62]. The K-Ar illite ages at $\sim 1455, \sim 1330$ and $\sim 1225 \mathrm{Ma}$ and the U-Pb ages of the same district are close to those determined by the $\mathrm{U}-\mathrm{Pb}$ method in other $\mathrm{U}$ deposits of the whole basin, at the unconformity with or in the basement of Cluff Lake [22], Cigar Lake [30,63], Key Lake and Hughes Lake [30], Sue Deposit [64], Rabbit Lake [30], McArthur River [40,65], Millennium [66,67] and Eagle Point [66]. Although the $1453 \pm 2$ Ma old event was not recorded directly by U-Pb dating in the Shea Creek deposit [68], U-Pb studies of sedimentary and basement rocks from the eastern Athabasca Basin suggest that the first $U$ mineralization stages occurred as early as $1450-550$ Ma in this area $[30,63,64,69]$. The idea that the regional age correlations with the K-Ar data of associated illite may not result systematically from each tectonic-thermal event cannot be completely excluded. Some of the thermal peaks could, for instance, have been registered by the $U$ ores and not by the associated illite and vice versa, depending on the type of event and the associated long-distance fluid migrations, as seems to have been the case for other metal deposits, such as in the southeastern Massif Central in France (e.g., [70]).

Criticizing published results has always been easier then consolidating a scenario with somewhat scattered results because of the high analytical uncertainties, or with "age" data obtained by various isotopic methods on various types of rocks. Interpretation of a priori unrelated data is even more complicated in a vast region that underwent a multi-episodic and, therefore, a complex tectonic-thermal history. For instance, the six mineralizing events claimed by Cumming and Kristic [30] at 1515, 1350, $1280,1000,575$ and $225 \mathrm{Ma}$ on the basis of a compilation of all U-Pb ages reported from entire Athabasca Basin still outline analytic uncertainties which make it tricky to combine, for instance, the older age at $1448 \pm 48$ Ma obtained here with the 1515-Ma record [28], even if the analytical uncertainties somehow favor the correlation. If the 1300-Ma event is no longer considered for an illite crystallization, it does not mean that it has not been recorded in other isotopic systems of other minerals, similar or not.

\subsection{Which Dating Benefits Can Result from Downsizing Clay Minerals?}

Selecting the most reliable age-meaning data from an isotopic database of illite-rich clay materials remains a challenge. If compared to the data of finer $(<0.2 \mu \mathrm{m})$ size fractions from the same samples, some values of the coarser fractions $(<2 \mu \mathrm{m})$ obtained here are too "old" to fit the regional evolution, implying, in turn, that they still contain detrital components and/or earlier crystallized minerals. Comparing the isotopic data of various size fractions from the same sample was not addressed as such for long in isotope dating of clay materials, because the rule was primarily based then on the collection of "appropriate" clay separates consisting of authigenic material. The fundamental step was not downsizing clay separates into smaller fractions, as an extremely valuable control in the search for the detrital components. However, as this distinction is still not systematically applicable, even for nanometer-sized separates of shales (e.g., $[19,71])$, a safe way to constrain best the isotopic data of clay minerals is to compare at least two size fractions of a few samples. By adding a supplementary 
analytical round that includes the separation and K-Ar dating of smaller $<0.2 \mu \mathrm{m}$ size fractions than in the previous study, it could be shown here that the coarser $<2 \mu \mathrm{m}$ fraction of the earlier dated sample 81-40 was almost devoid of older detrital or previously nucleated tectonic-thermal clay-types, and that the $<0.2 \mu \mathrm{m} \mathrm{K-Ar}$ value of one of the samples yields a quite close age at $922 \pm 22 \mathrm{Ma}$ to that of the $<2 \mu \mathrm{m}$ size fraction at $1020 \pm 20 \mathrm{Ma}$. This was not the case for the two other $-2 \mu \mathrm{m}$ size fractions for which the data differences amount between 300 and $400 \mathrm{Ma}$. The sizes of the selected fractions do not seem to be essential. However, to reach detrital emptiness it is probably better to select size fractions, (add a comma) which are markedly below the 2- $\mu$ m limit for the comparison.

In recent decades, the preparation of clay materials selected for isotopic dating evolved through a procedure progressively adapted to its specific application. Various leaching techniques also improved the cleaning of the clay minerals separated by sedimentation and centrifugation in distilled water. For instance, in the case of smectite-rich separates with many untied layers of diagenetic or slightly metamorphic host rocks, it is probably adequate to apply Jackson's [72] "cleaning" method in order to remove as much as possible the "free" cations that are easily hosted by such untied interlayers. As essential components for the K-Ar and the Rb-Sr methods, $\mathrm{K}$ and $\mathrm{Rb}$ that are not tied to the mineral structures need to be removed, because they are amenable to bias the final data if not fixed. However, the obtained age is then to be attributed to the nucleation of the illite layers and not to that of the K-empty smectite host. Of some importance in the correlation between crystal identification and age, any misapplied crystallographic interpretation can raise inappropriate conclusions (e.g., [73]). Since pure smectite does not contain any $\mathrm{K}$ and $\mathrm{Rb}$, its crystallization cannot be dated by either the $\mathrm{K}-\mathrm{Ar}$ or the Rb-Sr methods. In this respect, the progressive size decrease in separated fractions until the nanometer scale used since the late 1990s (e.g., [9]) helped improve the description of the mineral composition of the separates, contributing to the identification of the mineral types, which helped to better constrain the ages.

Last but not least, separating and selecting more than one representative size fraction of any selected sample provides a further analytical improvement that consolidates the interpretation of the historic evolution of clay-mineral host rocks. In detailing the different basic analytical steps of the isotopic dating of clay materials, it cannot be denied that an "investigation factor" exists, as each analytical combination depends on the background of the authors in charge of the isotopic analytical aspects. The preparation, separation, description and analytical steps vary in the published studies and, therefore, the details of the analytical steps are certainly helpful, including the mass-spectrometric methods and the precision controls. For instance, using varied types of acids to remove adsorbed cations from clay particles and/or dissolve the associated minerals sensitive to acid leaching is certainly acceptable, but all types and concentrations of acids do not impact the clay material similarly and, consequently, application tests are needed to check their impact and their routine use (e.g., [74]). The main reason for such controls is not in the evaluation of the impacts, but in the fact that the reliability of isotopic dating of clay minerals is probably at least as important in the preparation, identification and dating aspects of the analyzed clay fractions as in the geological situation of the host rocks.

\section{Conclusions}

In a previous publication, the K-Ar dating of $<2 \mu \mathrm{m}$ illite separates from the close vicinity of $U$ ores in the sandstone cover and the underneath gneissic basement of the Dominique Peter district in the circular Carswell structure (Saskatchewan, Canada) were interpreted as resulting from four regional tectonic-thermal episodes at $1447 \pm 45,1282 \pm 40$ and $1184 \pm 15$ Ma with a younger, less constrained episode at $900 \mathrm{Ma}$. Additional K-Ar ages of finer $<0.2 \mu \mathrm{m}$ illite separates from three samples analyzed previously for their sole $<2 \mu \mathrm{m}$ illite allowed to constrain the database by discarding the previous intermediate ages of $\sim 1280$ and $\sim 1185 \mathrm{Ma}$. The observed grouping of the data appears to result from mixtures of illite crystals of the framing tectonic-thermal events at $1448 \pm 48$ and $937 \pm 39( \pm 2 \sigma) \mathrm{Ma}$ and, therefore, have no strict historical value. The comparison of at least two size fractions extracted 
from highly indurated host rocks associated with $U$ ore deposits clearly focuses on the fact that such a comparison strengthens the real "ages" generated by the separated size fractions. Such evaluations of numerical isotopic data allow a more reliable sorting of the true ages of events that altered the host rocks, complicating, in turn, the historic evolution of the highly indurated rock types.

Isotopic dating of clay materials needs to be based on precisely described analytical methods when used. Constraining the historic reliability of isotopic ages is essential, especially on the basis of their preparation and on how the obtained ages of clay-type minerals are comparable to those of other isotopic methods applied to other types of minerals from various types of whole rocks.

Funding: This research was not funded specifically.

Acknowledgments: Sincere thanks are for P. Alexandre for his kind invitation to contribute to the Special Issue on "Geochemistry and Geochronology of Mineral Deposits", which gave me the opportunity to discuss analytical aspects in the clay material preparation for isotopic dating. Sincere thanks are also for A. Aubert and R. Boutin of the Laboratoire d'Hydrologie et de Géochimie de Strasbourg (University of Strasbourg) who contributed to the separation of the $<0.2 \mu \mathrm{m}$ fractions, the determination of their K contents and the XRD analyses, and to A. Todd of the CSIRO organization, Australia, who completed the Ar analyses of the $<0.2 \mu \mathrm{m}$ fractions. Finally, sincere thanks are also for two of the three anonymous reviewers for their very constructive and helpful comments, questions and remarks.

Conflicts of Interest: The author declares no conflict of interest.

\section{References}

1. Clauer, N.; Chaudhuri, S. Indirect Dating of Sediment-Hosted ore Deposits: Promises and Problems. In Isotopic Signatures and Sedimentary Records; Clauer, N., Chaudhuri, S., Eds.; Lecture Notes in Earth Sciences, Springer: Heidelberg, Germany, 2012; Volume 43, pp. 361-388.

2. Wasserburg, G.J.; Hayden, R.I.; Jensen, K.J. Ar40-K40 dating of igneous rocks and sediments. Geochim. Cosmochim. Acta 1956, 10, 153-165. [CrossRef]

3. Hurley, P.M.; Cormier, R.F.; Hower, J.; Fairbairn, H.W.; Pinson, W.H. Reliability of glauconite for age measurements by K-Ar and Rb-Sr methods. Am. Assoc. Pet. Geol. Bull. 1960, 44, 1793-1808.

4. Perry, E.A., Jr. Diagenesis and the K-Ar dating of shales and clay minerals. Geol. Soc. Am. Bull. 1974, 85, 827-830. [CrossRef]

5. Clauer, N.; Cocker, J.D.; Chaudhuri, S. Isotopic Dating of Diagenetic Illites in Reservoir Sandstones: Influence of the Investigator Effect. In Origin, Diagenesis, and Petrophysics of Clay Minerals in Sandstones; Special Publication; Society of Economic Paleontologists and Mineralogists: Broken Arrow, OK, USA, 1992; Volume 47, pp. 5-12.

6. Clauer, N.; Lerman, A. Thermal History Analysis of Sedimentary Basins: An Isotopic Approach to Illitization. In Thermal History Analysis of Sedimentary Basins: Methods and Case Histories; Special Publication; Harris, N.D., Peters, K., Eds.; Society of Economic Paleontologists and Mineralogists: Broken Arrow, OK, USA, 2012; Volume 11, pp. 125-146.

7. Szczerba, M.; Środoń, J. Extraction of diagenetic and detrital ages and of ${ }^{40} \mathrm{~K}_{\text {detrital }} /{ }^{40} \mathrm{~K}_{\text {diagenetic }}$ ratio from K-Ar dates of clay fractions. Clays Clay Miner. 2009, 57, 93-103. [CrossRef]

8. Thompson, G.R.; Hower, J. An explanation for low radiometric ages from glauconite. Geochim. Cosmochim. Acta 1973, 37, 1473-1491. [CrossRef]

9. Clauer, N.; Środoń, J.; Francu, J.; Sucha, V. K-Ar dating of illite fundamental particles separated from illite/smectite. Clay Miner. 1997, 32, 181-196. [CrossRef]

10. Clauer, N.; Chaudhuri, S. Clays in Crustal Environments. In Isotope Dating and Tracing; Springer: Berlin/Heidelberg, Germany; New York, NY, USA, 1995; 359p.

11. Liewig, N.; Clauer, N.; Sommer, F. Rb-Sr and K-Ar dating of clay diagenesis in Jurassic sandstone oil reservoir, North Sea. Am. Assoc. Pet. Geol. Bull. 1987, 71, 1467-1474.

12. Reuter, A. Implications of K-Ar ages of whole-rock and grain-size fractions of metapelites and intercalated metatuffs within an anchizonal terrane. Contrib. Mineral. Petrol. 1987, 97, 105-115. [CrossRef] 
13. Glasmann, J.R. The Fate of Feldspar in Brent Group Reservoirs, North Sea: A Regional Synthesis of Diagenesis in Shallow, Intermediate and Deep Burial Environments. In Geology of the Brent Group; Specia Publication; Morton, A.C., Haszeldine, R.S., Giles, M.R., Brown, S., Eds.; Geological Society of London: London, UK, 1992; Volume 61, pp. 329-350.

14. Matthews, J.C.; Velde, B.; Johansen, H. Significance of K-Ar ages of authigenic illitic clay minerals in sandstones and shales from the North Sea. Clay Miner. 1994, 29, 379-389. [CrossRef]

15. Zwingmann, H.; Berger, A.; Eggenberger, U.; Todd, A.; Herwegh, M. Testing high-voltage electrical discharges in disintegrating claystone for isotopic and mineralogical studies: An example using Opalinus Claystone. Clays Clay Miner. 2017, 65, 342-354. [CrossRef]

16. Środoń, J.; Elsass, F.; McHardy, W.J.; Morgan, D.J. Chemistry of illite/smectite inferred from TEM measurements of fundamental particles. Clay Miner. 1992, 27, 137-158. [CrossRef]

17. Nadeau, P.H.; Wilson, M.J.; McHardy, W.J.; Tait, J.M. Interstratified clays as fundamental particles. Science 1984, 225, 923-925. [CrossRef] [PubMed]

18. Clauer, N.; Liewig, N.; Pierret, M.C.; Toulkeridis, T. Crystallization conditions of fundamental particles from mixed-layers illite-smectite of bentonites based on isotopic data (K-Ar, $\mathrm{Rb}-\mathrm{Sr}$ and $\left.\delta^{18} \mathrm{O}\right)$. Clays Clay Miner. 2003, 51, 664-674. [CrossRef]

19. Clauer, N.; Rousset, D.; Srodon, J. Modeled shale and sandstone burial diagenesis based on the K-Ar systematics of illite-type fundamental particles. Clays Clay Miner. 2003, 52, 576-588. [CrossRef]

20. Clauer, N.; Honty, M.; Fallick, A.E.; Sucha, V.; Aubert, A. Regional illitization in bentonite beds from East Slovak Basin based on isotopic characteristics (K-Ar, $\delta^{18} \mathrm{O}$ and $\left.\delta \mathrm{D}\right)$ of illite-type nanoparticles. Clay Miner. 2014, 49, 247-275. [CrossRef]

21. Honty, M.; Uhlík, P.; Sucha, V.; Caplovicová, M.; Francù, J.; Clauer, N.; Biron, A. Smectite-to-illite alteration in salt-bearing bentonites (the East Slovak Basin). Clays Clay Miner. 2004, 52, 533-551. [CrossRef]

22. Philippe, S.; Lancelot, J.R.; Clauer, N.; Pacquet, A. Formation and evolution of the Cigar Lake uranium deposit based on U-Pb and K-Ar isotope systematics. Can. J. Earth Sci. 1993, 30, 720-730. [CrossRef]

23. Harper, C.T. Graphic solution to the problem of ${ }^{40} \mathrm{Ar}$ loss from metamorphic minerals. Eclogae Geol. Helv. 1970, 63, 119-140.

24. Lewry, J.F.; Sibbald, T.I.I.; Rees, C.J. Metamorphic Patterns and their relation to tectonism and plutonism in the Churchill Province in northern Saskatchewan. In Metamorphism in the Canadian Shield, Geological Survey of Canada Paper 78-100; Geological Society of America: Boulder, CO, USA, 1978; pp. 139-154.

25. Bruneton, P. Geological environment of the Cigar Lake uranium deposit. Can. J. Earth Sci. 1993, 30, 653-673. [CrossRef]

26. Cumming, G.L.; Rimsaite, J. Isotopic studies of lead-depleted pitchblende, secondary radioactive minerals, and sulphides from the Rabbit Lake uranium deposit, Saskatchewan. Can. J. Earth Sci. 1979, 16, 1702-1715. [CrossRef]

27. Baadsgaard, H.; Cumming, G.L.; Worden, J.M. U-Pb geochronology of minerals from the Midwest uranium deposit, northern Saskatchewan. Can. J. Earth Sci. 1984, 21, 642-648. [CrossRef]

28. Fryer, B.J.; Taylor, R.P. Rare-earth element distributions in uraninites: Implications for ore genesis. Chem. Geol. 1984, 63, 101-108. [CrossRef]

29. Trocki, L.K.; Curtis, D.B.; Gancarz, A.J.; Banar, J.C. Ages of major uranium mineralization and Pb loss in the Key Lake uranium deposit, northern Saskatchewan, Canada. Econ. Geol. 1984, 79, 1378-1386. [CrossRef]

30. Cumming, G.L.; Krstic, D. The age of unconformity-related uranium mineralization in the Athabasca Basin, northern Saskatchewan. Can. J. Earth Sci. 1992, 29, 1623-1639. [CrossRef]

31. Carl, C.; von Pechmann, E.; Höhndorf, A.; Ruhrmann, G. Mineralogy and U/Pb, $\mathrm{Pb} / \mathrm{Pb}$, and $\mathrm{Sm} / \mathrm{Nd}$ geochronology of the Key Lake uranium deposit, Athabasca Basin, Saskatchewan, Canada. Can. J. Earth Sci. 1992, 29, 879-895. [CrossRef]

32. Bellon, H.; Devillers, C.; Hageman, R.; Touray, J.C. Dater les minéralisations. Mémoire hors Série. Société Géologique Fr. 1976, 7, 265-268.

33. Devillers, C.; Menes, J. Datation de la Minéralisation d'Akouta, République du Niger: Complément, Rapport DRA/SAECNI/77, DR62/123/CD/DT1977. 7-15.

34. Bell, K. Geochronology of the Carwell Area and Northern Saskatchewan. In The Carswell Structure Deposits, Saskatchewan; Special Paper; Laine, R., Alonso, D., Svab, L., Eds.; Geological Association of Canada: St. John's, NL, Canada, 1985; Volume 29, pp. 33-46. 
35. Clauer, N.; Ey, F.; Gauthier-Lafaye, F. K-Ar Dating of Different Rock Types from the Cluff Lake Uranium Ore Deposits (Saskatchewan-Canada). In The Carswell Structure Uranium Deposits, Saskatchewan; Special Paper; Lainé, R., Alonso, D., Svab, M., Eds.; Geological Association of Canada: St. John's, NL, Canada, 1985; Volume 29, pp. 47-54.

36. Laverret, E.; Clauer, N.; Fallick, A.; Mercadier, J.; Patrier, P.; Beaufort, D.; Bruneton, P. K-Ar dating and $\delta^{18} \mathrm{O}-\delta \mathrm{D}$ tracing of illitization within and outside the Shea Creek uranium prospect, Athabasca Basin, Canada. Appl. Geochem. 2010, 25, 856-871. [CrossRef]

37. Turpin, L.; Clauer, N.; Forbes, P.; Pagel, M. U-Pb, Sm-Nd and K-Ar systematics of the Akouta uranium deposit, Niger. Chem. Geol. (Isot. Geosci.) 1991, 87, 217-230. [CrossRef]

38. Respaut, J.P.; Cathelineau, M.; Lancelot, J. Multistage evolution of the Pierres Plantées uranium ore deposit (Margeride, France): Evidence from mineralogy and U-Pb systematics. Eur. J. Mineral. 1991, 3, 85-103. [CrossRef]

39. Alexandre, P.; Kyser, K.; Thomas, D.; Polito, P.; Marlat, J. Geochronology of unconformity-related uranium deposits in the Athabasca Basin, Saskatchewan, Canada and their integration in the evolution of the basin. Miner. Depos. 2009, 44, 41. [CrossRef]

40. Alexandre, P.; Kyser, P.; Polito, P.; Thomas, D. Geochronology of unconformity-related uranium deposits in the Athabasca Basin, Saskatchewan, Canada and their integration in the evolution of the basin. Econ. Geol. 2005, 100, 1547-1563. [CrossRef]

41. Juteau, M.; Pagel, M.; Michard, A.; Albarède, F. Assimilation of continental crust by komatiites in the Precambrian basement of the Carswell structure (Saskatchewan, Canada). Contrib. Mineral. Petrol. 1988, 99, 219-225. [CrossRef]

42. Cumming, G.L.; Krstic, D.; Wilson, J.A. Age of the Athabasca Group, Northern Alberta. In Proceedings of the GAC-MAC Annual Conference, Saskatoon, SK, Canada, 25-27 May 1987; p. 35.

43. Armstrong, R.L.; Ramaekers, P. Sr isotopic study of Helikian sediment and diabase dikes in the Athabasca Basin, northern Saskatchewan. Can. J. Earth Sci. 1985, 22, 399-407. [CrossRef]

44. Pagel, M.; Weatley, K.; Ey, F. The Origin of the Carwell Circular Structure. In The Carswell Structure Deposits, Saskatchewan; Special Paper; Laine, R., Alonso, D., Svab, L., Eds.; Geological Association of Canada: St. John's, NL, Canada, 1985; Volume 29, pp. 213-223.

45. Wanless, R.D.; Stevens, R.D.; Lachance, G.R.; Delabio, R.N. Age Determinations and Geological Studies, K-Ar Isotopic Ages; Report 14; Geological Survey of Canada: Ottawa, ON, Canada, 1979.

46. Bottomley, R.J.; York, D.; Grieve, R.A.F. Argon-40-Argon-39 Dating of Impact Craters. In Proceedings of the 20th Lunar and Planetary Science Conference, Houston, TX, USA, 12-16 March 1990; pp. 421-431.

47. Pagel, M.; Svab, M. Petrographic and Geochemical Variations within the Carswell Structure Metamorphic Core and their Implications with Respect to Uranium Mineralization; Special Papers; Geological Association of Canada: St. John's, NL, Canada, 1985; Volume 29, pp. 55-70.

48. Pagel, M.; Ruhlmann, F. Chemistry of Uranium Minerals in Deposits and Showings of the Carswell Structure (Saskatchewan-Canada). In The Carswell Structure Deposits, Saskatchewan; Special Paper; Laine, R., Alonso, D., Svab, L., Eds.; Geological Association of Canada: St. John's, NL, Canada, 1985; Volume 29, pp. 154-164.

49. Ey, F. Un Exemple de Gisement D'uranium Sous Discordance: Les Minéralisations Protérozö̈ques de Cluff Lake, Saskatchewan, Canasa; Thèse de Spécialité: Université Louis Pasteur: Strasbourg, France, 1984.

50. Bonhomme, M.G.; Thuizat, R.; Pinault, Y.; Clauer, N.; Wendling, A.; Winkler, R. Méthode de Datation Potassium-Argon. Appareillage et Technique; Note Technique; Institut Géologie: Strasbourg, France, 1975.

51. Odin, G.S. (Ed.) Odin and 36 Collaborators Interlaboratory Standards for Dating Purposes. In Numerical Dating in Stratigraphy; John Wiley \& Sons: Chichester, UK, 1982; Part 1; pp. 123-148.

52. Lee, J.Y.; Marti, K.; Severinghaus, J.P.; Kawamura, K.; Yoo, H.S.; Lee, J.B.; Kim, J.S. A redetermination of the isotopic abundances of atmospheric Ar. Geochim. Cosmochim. Acta 2006, 70, 4507-4512. [CrossRef]

53. Steiger, R.H.; Jäger, E. Subcommision on geochronology: Convention on the use of decay constants in geoand cosmochronology. Earth Planet. Sci. Lett. 1977, 36, 359-362. [CrossRef]

54. Kübler, B. Evaluation Quantitative du Métamorphisme Par la Cristallinité de L'illite. Bulletin Centre de Recherche de Pau; Société Nationale des Pétrole d'Aquitaine: Pau, France, 1968; pp. 285-397.

55. Kübler, B. Concomitant Alteration of Clay Minerals and Organic Matter during Burial Diagenesis. In Soils and Sediments; Paquet, H., Clauer, N., Eds.; Springer: Berlin/Heidelberg, Germany, 1997; pp. 327-362. 
56. Merriman, R.J.; Frey, M. Patterns of Very Low-Grade Metamorphism in Metapelitic Rocks. In Low-Grade Metamorphis; Frey, M., Robinson, D., Eds.; Blackwell Science: Oxford, UK, 1999; pp. 61-107.

57. Klug, H.P.; Alexander, L.E. X-Ray Diffraction Procedures, 2nd ed.; Wiley: New York, NY, USA, 1974; 992p.

58. Arkai, P.; Toth, N.M. Illite crystallinity: Combined effects of domain size and lattice distortion. Acta Geol. Hung. 1983, 26, 341-348.

59. Eberl, D.D.; Velde, B. Beyond the Kübler index. Clay Miner. 1989, 24, 571-577. [CrossRef]

60. Laverret, E.; Patrier-Mas, P.; Beaufort, D.; Kister, P.; Quirt, D.; Bruneton, P.; Clauer, N. Mineralogy and geochemistry of the host-rock alterations associated with the Shea Creek unconformity-type uranium deposit (Athabasca Basin, Saskatchewan, Canada). Part 1. Spatial variation of illite properties. Clays Clay Miner. 2006, 54, 275-294. [CrossRef]

61. Lorilleux, G.; Jébrak, M.; Cuney, M.; Baudemont, D. Polyphase hydrothermal breccias associated with unconformity-related uranium mineralization (Canada): From fractal analysis to structural significance. J. Struct. Geol. 2002, 24, 323-338. [CrossRef]

62. Kister, P.; Laverret, E.; Quirt, D.; Cuney, M.; Patrier-Mas, P.; Beaufort, D.; Bruneton, P. Mineralogy and geochemistry of the host-rock alterations associated with the Shea Creek unconformity-type uranium deposits (Athabasca Basin, Saskatchewan, Canada). Part 2. Regional-scale spatial distribution of the Athabasca group sandstone matrix minerals. Clays Clay Miner. 2006, 54, 295-313. [CrossRef]

63. Fayek, M.; Harrison, T.M.; Ewing, R.C.; Grove, M.; Coath, C.D. O and Pb isotopic analyses of uranium minerals by ion microprobe and U-Pb ages from the Cigar Lake deposit. Chem. Geol. 2002, 185, 205-225. [CrossRef]

64. Fayek, M.; Kyser, T.K.; Riciputi, L. U and Pb isotope analysis of uranium minerals by ion microprobe and the geochronology of the McArthur River and Sue Zone uranium deposits, Saskatchewan, Canada. Can. Mineral. 2002, 40, 1553-1569. [CrossRef]

65. Alexandre, P.; Kyser, T.K.; Jiricka, D. Critical geochemical and mineralogical factors for the formation of unconformity-related uranium deposits: Comparison between barren and mineralized systems in the Athabasca Basin, Canada. Econ. Geol. 2009, 104, 413-435. [CrossRef]

66. Mercadier, J. Conditions de Genèse des Gisements D'uranium Associés aux Discordances Protérozoïques et Localisés Dans les Socles. Exemple du Socle du Bassin d'Athabasca (Saskatchewan, Canada). Ph.D. Thesis, Institut National Polytechnique de Lorraine, Nancy, France, 2008.

67. Cloutier, J.; Kyser, K.; Olivo, G.R.; Alexandre, P.; Halaburda, J. The millennium uranium deposit, Athabasca Basin, Saskatchewan, Canada: An atypical basement-hosted unconformity-related uranium deposit. Econ. Geol. 2009, 104, 815-840. [CrossRef]

68. Kister, P. Mobilité des Éléments Géochimiques Dans un Bassin Sédimentaire Clastique, du Protérozoïque à Nos Jours: Le Bassin Athabasca (Saskatchewan, Canada). Unpublished Ph.D. Thesis, Institut National Polytechnique de Lorraine, Nancy, France, 2003; 333p.

69. Alexandre, P.; Kyser, T.K. Effects of cationic substitution and alteration in uraninite, and implications for the dating of uranium deposits. Can. Mineral. 2005, 43, 1005-1017. [CrossRef]

70. Clauer, N. The post-Variscan tectonic-thermal activity in the southeastern metalliferous province of the French Massif Central revisited by K-Ar ages of illite. Ore Geol. Rev. 2019, 117. [CrossRef]

71. Clauer, N.; Chaudhuri, S. Extracting K-Ar ages from shales: The analytical evidence. Clay Miner. 2001, 36, 227-235. [CrossRef]

72. Jackson, M.L. Soil chemical Analysis-Advanced Course; UW-Madison Libraries Parallel Press: Madison, WI, USA, 1975; 386p.

73. Nakata, E.; Yukawa, M.; Okumura, H.; Hamada, M. K-Ar dating by smectite extracted from bentonite formations. E3S Web Conf. 2019, 98, 12015. [CrossRef]

74. Clauer, N.; Chaudhuri, S.; Kralik, M.; Bonnot-Courtois, C. Effects of experimental leaching on Rb-Sr and K-Ar isotopic systems and REE contents of diagenetic illite. Chem. Geol. 1993, 103, 1-16. [CrossRef]

(C) 2020 by the author. Licensee MDPI, Basel, Switzerland. This article is an open access article distributed under the terms and conditions of the Creative Commons Attribution (CC BY) license (http://creativecommons.org/licenses/by/4.0/). 